\title{
ANALISIS SALURAN PEMASARAN TEPUNG AREN (Studi Kasus di Desa Kertaharja Kecamatan Cijeungjing Kabupaten Ciamis)
}

\author{
MARKETING ANALYSIS OF FALM FLOUR CHANNEL \\ (Case Study In Kertaharja Village, Cijeugjing District, Ciamis Regency)
}

DETI RATNA SUMINAR ${ }^{1 *}$, TRISNA INSAN NOOR ${ }^{2}$, DANI LUKMAN HAKIM ${ }^{1}$

${ }^{1}$ Fakultas Pertanian Universitas Galuh

${ }^{2}$ Fakultas Pertanian Universitas Padjajaran

*Email : deti.ratna69@gmail.com.

\begin{abstract}
ABSTRAK
Penelitian ini bertujuan untuk mengetahui: (1) saluran pemasaran tepung aren di Desa Kertaharja Kecamatan Cijeungjing Kabupaten Ciamis, (2) besarnya margin, biaya dan keuntungan pemasaran tepung aren, (3) besarnya bagian harga yang diterima produsen (producer's share), (4) dan efisiensi pemasaran tepung aren di Desa Kertaharja Kecamatan Cijeungjing Kabupaten Ciamis. Metode penelitian yang digunakan adalah studi kasus. Data yang diperoleh terdiri dari data primer dan data sekunder. Jumlah responden dalam penelitian ini adalah sebanyak delapan belas orang yang terdiri dari 3 produsem, satu pedagang pengepul, 2 pedagang besar dan 12 pedagang pengecer. Hasil penelitian menunjukan bahwa : Terdapat satu saluran pemasaran tepung aren sampai ke tangan konsumen akhir yaitu : Saluran Pemasaran: Produsen $\rightarrow$ Pedagang Pengepul $\rightarrow$ Pedagang Besar $\rightarrow$ Pedagang Pengecer $\rightarrow$ Konsumen Akhir. Pada saluran ini melibatkan beberapa lembaga pemasaran yaitu pedagang pengepul, pedagang besar dan pedagang pengecer. Besarnya margin pemasaran pada saluran ini adalah sebesar Rp. 2.000,- per kilogram sehingga keuntungan total pemasaran sebesar Rp. $1.635,-$ per kilogram. Besarnya bagian harga yang diterima produsen (producer's share) pada saluran pemasaran ini adalah sebesar 77,77 persen. Total biaya yang dikeluarkan selama proses pemasaran tepung aren adalah Rp. 365,- per kilogram, total keuntungan pemasarannya Rp. 1.635,- per kilogram. Bila dilihat dari saluran pemasarannya, saluran pemasaran tepung aren ini efisien yaitu sebesar $0,05 \%$.
\end{abstract}

Kata kunci : Biaya, efisiensi pemasaran, keuntungan pemasaran, margin pemasaran, producer's share.

\begin{abstract}
The study aimed to know: (1) marketing channels of palm flour in Kertaharja Village, Cijeungjing District, Ciamis Regency, (2) the amount of margins, costs and marketing benefits of palm flour, (3) The margin of the producer's share, (4) and the efficiency of marketing palm sugar sugar flour in Kertaharja Village, Cijeungjing District, Ciamis Regency. The research method used was a case study. The data obtained consists of primary data and secondary data. The number of respondents in this study were eighteen persons, consists of 3 producers, one trader, 2 wholesalers and 12 retailers. The results of the result showed that: There channel sugar palm flour marketing to the end consumer, i.e: Was only one : Producer $\rightarrow$ Trader $\rightarrow$ Large $\rightarrow$ Traders Retailers $\rightarrow$ Costumer. The channel involved several marketing institutions, i.e traders, wholesalers and retailers. The amount of marketing margin on this channel was Rp. 2.000,- per kilogram thus that the total marketing profit was $R$ p. 1,635,- per kilogram. The margin received by producers (producer's share) in this marketing channel was 77.77 percent. Total costs incurred during the marketing process of sugar palm flour was Rp. 365,- per kilogram, the total marketing profit was Rp. 1,635,- per kilogram. It concluded that the marketing channel of sugar falm flour in this study was protitable at 0,05\%.
\end{abstract}

Keyword: Costs, margin, marketing benefits, marketing efficiency, producer's share. 


\section{PENDAHULUAN}

\section{Latar Belakang}

Pertanian memegang peranan penting dalam ekonomi Indonesia. Secara konvensional, peran tersebut terkait fungsi menjaga ketahanan pangan (food security), penyerapan tenaga kerja, penghasil devisa, penyedia bahan baku industri, dan penjaga kelestarian lingkungan. Meskipun industri dalam jangka panjang akan menjadi engine of growth, tetapi besar jumlah penduduk yang hidup di sektor semi tradisional tersebut membuat pertanian sebagai medan juang yang tak akan pernah berakhir. Transformasi struktural dari ekonomi berbasis pertanian dan sumber daya alam ke arah industri tampaknya masih akan tergantung pada tingkat kesiapan sektor pertanian (Hanafie, 2010).

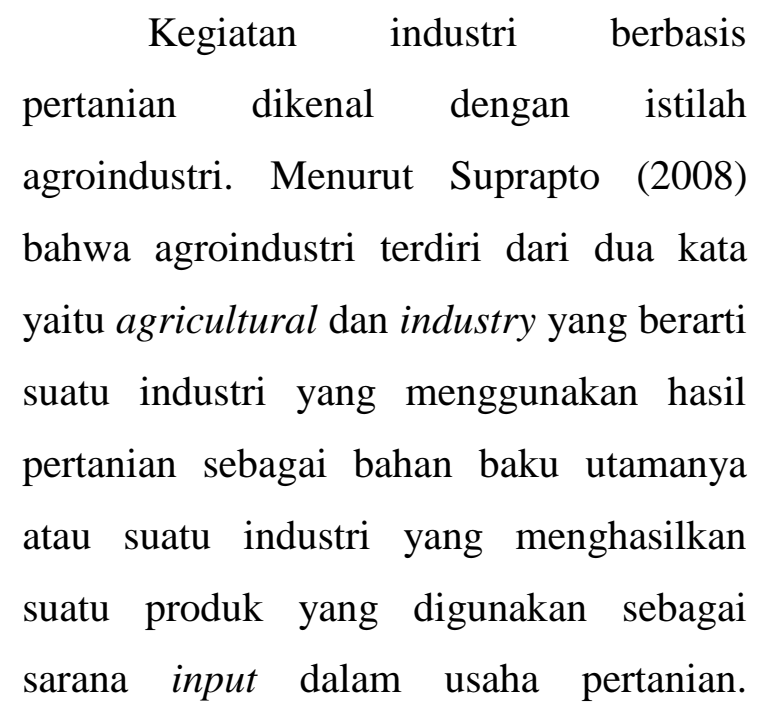
Agroindustri merupakan bagian susbsistem yang memproses dan mentransformasikan bahan-bahan hasil pertanian yang mana sari pati menjadi barang-barang setengah jadi yang langsung dikonsumsi dan barang hasil produksi industri yang digunakan dalam proses industri. Dalam kerangka pengembangan agroindustri merupakan penggerak utama pengembangan sektor pertanian terlebih masa yang akan datang posisi pertanian merupakan sektor andalan dalam pembangunan nasional sehingga peranan agroindustri akan semakin besar.

Industri tepung aren telah terdapat di berbagai wilayah di Indonesia, misalnya di Kecamatan Cijeungjing Kabupaten Ciamis. Industri tepung aren di wilayah ini masih dikelola oleh masyarakat setempat.

Aren (Arenga pinnata) merupakan salah satu tananam perkebunan yang dibudidayakan di Indonesia. Hal ini dikarenakan aren termasuk tanaman yang memiliki nilai ekonomis, karena hampir seluruh tanamannya dapat dimanfaatkan oleh masyarakat. Salah satu komoditas yang dihasilkan oleh pohon aren adalah tepung aren. Bahan baku tepung aren adalah batang aren (Arenga pinnata), yang ditebang setelah berumur kira-kira 15 tahun, sebelum atau sesudah pohon aren tersebut berbunga untuk mencapai umur itu. Ada tiga pilihan perlakuan pada pohon aren, pertama ditebang untuk diambil patinya, dipersiapkan untuk disadap 
niranya atau dipersiapkan untuk diambil buahnya.

Tepung aren adalah salah satu bahan pangan lokal yang menjadi alternatif untuk menunjang diversifikasi pangan. Adanya agroindustri tepung aren yang bermunculan sehingga negara bisa mengurangi ketergantungan produk berbahan baku impor

\section{METODE PENELITIAN}

\section{Jenis Penelitian}

Metode penelitian yang digunakan adalah Kualitatif dengan jenis Penelitian studi kasus pada agroindustri tepung aren di Desa Kertaharja Kecamatan Cijeungjing Kabupaten Ciamis. Menurut Sukandarrumidi (2006), metode studi kasus merupakan penelitian yang mendalam mengenai kasus tersebut dan tidak bisa digeneralisasi pada yang luar di kasus tersebut.

\section{Teknik Penarikan Informan}

Informan dalam penelitian ini adalah 3 (tiga) perusahaan tepung aren di Desa Kertaharja Kecamatan Cijeungjing Kabupaten Ciamis yang terdapat di Dinas Perindustrian dan Perdagangan Kabupaten Ciamis.

Selanjutnya untuk mendapatkan informan pelaku pemasaran yang terkait dengan ketiga perusahaan tepung aren tersebut dilakukan secara snowball. Berdasarkan pendekatan tersebut diperoleh 1 orang pedagang pengepul, 2 orang pedagang besar dan 15 pedagang pengecer.

\section{Rancangan Analisis Data}

1) Biaya pemasaran adalah semua biaya yang sejak saat produk selesai diproduksi dan disimpan dalam gudang sampai dengan produk tersebut berubah kembali dalam bentuk uang tunai (Mulyadi, 1991). Besarnya biaya pemasaran tepung aren dapat dihitung dengan menggunakan rumus sebagai berikut :

$$
B p=B p 1+B p 2+B p 3+\ldots . . B p n
$$

$$
\begin{aligned}
& \text { Keterangan : } \\
& \begin{array}{l}
\text { Bp : Biaya pemasaran tepung } \\
\text { aren }
\end{array} \\
& \begin{array}{l}
\text { Bp1, Bp2, Bp3,..., Bpn : Biaya } \\
\text { pemasaran tepung aren } \\
\text { berdasarkan saluran/tempat } \\
\text { pemasaran. }
\end{array}
\end{aligned}
$$

2) Margin pemasaran adalah selisih harga ditingkat produsen dan tingkat konsumen. Secara matematis margin pemasaran dirumuskan sebagai berikut

$$
\mathbf{M p}=\mathbf{P r}-\mathbf{P f}
$$

Keterangan :

$$
\begin{array}{cc}
\text { Mp } \quad \begin{array}{c}
\text { : Margin pemasaran tepung } \\
\text { aren }(\mathrm{Rp} / \mathrm{kg})
\end{array} \\
\text { Pr } \quad \begin{array}{c}
\text { Harga tepung aren untuk } \\
\text { konsumen }(\mathrm{Rp} / \mathrm{kg})
\end{array} \\
\text { Pf } \quad \begin{array}{c}
\text { : Harga tepung aren untuk } \\
\text { produsen }(\mathrm{Rp} / \mathrm{kg})
\end{array}
\end{array}
$$


3) Efisiensi pemasaran dihitung dengan menggunakan rumus sebagai berikut (Soekarwati, 2005) :

$$
\mathrm{EP}=\frac{\mathrm{TB}}{\mathrm{TNP}} \mathrm{X} 100 \%
$$

Dimana ;

$\mathrm{EP}=$ Efisiensi Pemasaran $(\%)$

$\mathrm{TB}=$ Total Biaya Pemasaran $(\mathrm{Rp})$

TNP = Total Nilai Produk (kg)

Kaidah keputusan pada efisiensi pemasaran ini adalah :
1. $0-33 \%=$ efisien
2. $34-67=$ kurang efisien
3. $68-100=$ tidak efisien

4) Untuk mengetahui bagian harga yang diterima produsen (producer's share) menggunakan rumus (Sutarno, 2014) sebagai berikut :

$$
\begin{aligned}
& S p=\frac{P f}{P r} \times 100 \% \\
& \mathrm{Sp}=\text { Bagian harga yang diterima } \\
& \text { produsen (produser's share) } \\
& \mathrm{Pf}=\text { Harga di tingkat produsen } \\
& (\mathrm{Rp} / \mathrm{kg}) \\
& \mathrm{Pr}=\text { Harga di tingkat lembaga } \\
& \text { pemasaran }(\mathrm{Rp} / \mathrm{kg})
\end{aligned}
$$

\section{HASIL DAN PEMBAHASAN}

\section{Saluran Pemasaran Tepung Aren}

Saluran pemasaran merupakan jalur dari lembaga-lembaga pemasaran yang mempunyai kegiatan yang menyalurkan barang-barang dari produsen ke konsumen. Berdasarkan penelitian yang telah dilaksanakan, dapat diketahui pola saluran tepung aren di Desa Kertaharja Kecamatan Cijeungjing Kabupaten Ciamis pada Gambar 7 adalah sebagai berikut :



\section{Gambar 7.}

Saluran Pemasaran Tepung Aren di Desa Kertaharja Kecamatan Cijeungjing Kabupaten Ciamis

Gambar 7 menunjukkan bahwa proses pemasaran tepung aren sampai ke konsumen akhir melalui 3 lembaga pemasaran yaitu pedagang pengepul, pedagang besar dan pedagang pengecer. Saluran pemasaran inti terdiri dari 1 saluran yaitu sebagai berikut :

Saluran satu : Produsen - pedagang pengepul - pedagang besar - pedagang pengecer - konsumen

\section{Analisis Margin, Biaya, dan} Keuntungan Pemasaran Tepung Aren

\section{a. Analisis Margin Pemasaran}

Margin pemasaran tepung aren pada masing-masing lembaga pemasaran adalah selisih harga antara harga jual dan 
harga beli di masing-masing lembaga pemasaran. Dalam penelitian ini, perhitungan margin pemasaran dilakukan pada satu saluran pemasaran seperti dilihat pada tabel 1.

Tabel 1. Rata-rata Harga dan Margin Pemasaran Tepung Aren pada setiap Lembaga Pemasaran

\begin{tabular}{lr}
\hline Unsur Pemasaran & Saluran 1 (Rp/Kg) \\
\hline Harga & 7.000 \\
Pedagang pengepul & 7.000 \\
- Harga beli & 7.500 \\
- Harga jual & 500 \\
- Margin pemasaran & \\
Pedagang besar & 7.500 \\
- Harga beli & 8.000 \\
- Harga jual & 500 \\
- Margin pemasaran & \\
Pedagang pengecer & 8.000 \\
- Harga beli & 9.000 \\
- Harga jual & 1.000 \\
\hline$\quad \quad$ Margin pemasaran & \\
\hline Sumber : Hasil Analisis, (2019)
\end{tabular}

Tabel 1 menunjukkan bahwa margin pemasaran pada saluran 1 adalah sebesar Rp. 2.000,- perkilogram. Masingmasing saluran pemasaran 1 adalah pedagang pengepul sebesar Rp. 500,perkilogram, pedagang besar sebesar Rp. 500,- perkilogram dan pedagang pengecer sebesar Rp. 1.000,- perkilogram.

\section{Analisis Keuntungan Pemasaran}

Keuntungan pemasaran merupakan pengurangan antara margin pemasaran dan biaya pemasaran. Biaya pemasaran merupakan komponen penting dalam margin pemasaran. Dalam penelitian ini biaya pemasaran merupakan biaya yang dikeluarkan dalam proses pemasaran suatu produk oleh lembaga pemasaran dalam rangka menyalurkan tepung aren dari produsen ke konsumen.

Tabel 2. Rata- rata Biaya, Margin dan Keuntungan pada Pedagang Pengepul

\begin{tabular}{llr}
\hline No. & \multicolumn{1}{c}{ Uraian } & \multicolumn{1}{c}{$\begin{array}{c}\text { Saluran 1 } \\
(\mathbf{R p} / \mathbf{k g})\end{array}$} \\
\hline & Biaya & $30,-$ \\
1. & Kuli Angkut & $60,-$ \\
2. & Transfortasi & $90,-$ \\
& Jumlah & $500,-$ \\
3. & Margin & $410,-$ \\
4. & Keuntungan
\end{tabular}

Tabel 2 menunjukkan bahwa biaya rata-rata yang dikeluarkan oleh pedagang pengepul pada saluran 1 adalah sebesar Rp. 90,-. Margin pemasaran pedagang pengepul pada saluran 1 adalah sebesar Rp. 500,- dan mendapat keuntungan ratarata yang diperoleh adalah sebesar Rp. 410,-.

Tabel 3. Rata-Rata Biaya, Margin, dan Keuntungan pada Pedagang Besar.

\begin{tabular}{clr}
\hline No. & \multicolumn{1}{c}{ Uraian } & Saluran 1 (Rp/kg) \\
\hline & Biaya & $30,-$ \\
1. & Kuli Angkut & $75,-$ \\
2. & Transfortasi & $105,-$ \\
& Jumlah & $500,-$ \\
3. & Margin & $395,-$ \\
4. & Keuntungan &
\end{tabular}

Sumber : Hasil Analisis, (2019). 
Tabel 3 menunjukkan bahwa ratarata yang dikeluarkan oleh pedagang besar pada saluran 1 adalah sebesar Rp. 105,-. Margin pemasaran pedagang besar pada saluran 1 adalah sebesar Rp. 500,- dan mendapat keuntungan rata-rata diperoleh adalah sebesar Rp. 395,-

Tabel 4. Rata-rata Biaya, Margin, dan Keuntungan Pemasaran pada Pedagang Pengecer

\begin{tabular}{clr}
\hline No. & \multicolumn{1}{c}{ Uraian } & \multicolumn{2}{c}{$\begin{array}{c}\text { Saluran 1 } \\
\text { (Rp/kg) }\end{array}$} \\
\hline 1. & Biaya & $120,-$ \\
& Kuli angkut & $50,-$ \\
2. & Transfortasi & $170,-$ \\
& Jumlah & $1.000,-$ \\
3. & Margin & $830,-$ \\
4. & Keuntungan
\end{tabular}

Sumber : Hasil Analisis, (2019).

Tabel 4 menunjukkan bahwa ratarata biaya yang dikeluarkan pedagang pengecer pada saluran pemasaran 1 adalah sebesar Rp. 170,- perkilogram, dengan margin pemasaran sebesar Rp. 1000,perkilogram dan mendapat keuntungan sebesar Rp. 830,- perkilogam.
Tabel 5. Rata-rata Margin dan Keuntungan Pemasaran Tepung Aren di Desa Kertaharja pada Saluran 1

\begin{tabular}{lccc}
\hline $\begin{array}{c}\text { Perlakuan } \\
\text { pemasaran }\end{array}$ & $\begin{array}{c}\text { Margin } \\
\text { pemasaran } \\
\text { Rata-rata } \\
(\mathbf{R p} / \mathbf{k g})\end{array}$ & $\begin{array}{c}\text { Biaya } \\
\text { pemasaran } \\
\text { Rata-rata } \\
(\mathbf{R p} / \mathbf{k g})\end{array}$ & $\begin{array}{c}\text { Keuntung } \\
\mathbf{a n} \\
(\mathbf{R p} / \mathbf{k g})\end{array}$ \\
\hline $\begin{array}{l}\text { Saluran 1 } \\
\text { - Pedagang } \\
\text { Pengepul }\end{array}$ & $500,-$ & $90,-$ & $410,-$ \\
$-\begin{array}{l}\text { Pedagang } \\
\text { Besar }\end{array}$ & $500,-$ & $105,-$ & $395,-$ \\
$-\begin{array}{l}\text { Pedagang } \\
\text { Pengecer }\end{array}$ & $1000,-$ & $170,-$ & $830,-$ \\
\hline
\end{tabular}

Sumber : Hasil Analisis (2019).

Tabel 13 menunjukkan bahwa pada saluran pemasaran 1 pedagang pengepul mendapatkan margin pemasaran sebesar Rp. 500,- perkilogram dengan rata-rata biaya pemasaran sebesar Rp.90,perkilogram sehingga mendapatkan keuntungan sebesar Rp. 410,- perkilogram karena pedagang pengepul disini berperan sebagai produsen. Pedagang besar mendapatkan margin sebesar Rp. 500,dengan biaya rata-rata pemasaran sebesar Rp. 105,- perkilogram dan mendapatkan keuntungan sebesar Rp. 395,- perkilogram. Pedagang pengecer mendapatkan margin sebesar Rp. 1.000,- perkilogram dengan biaya pemasaran sebesar Rp. 170,perkilogram dan mendapatkan keuntungan sebesar Rp. 830,- perkilogram. 


\section{Producer's Share Atau Persentase}

\section{Bagian Harga yang Diterima Produsen}

Berdasarkan hasil penelitian bahwa harga jual tepung aren dari produsen ke pedagang pedagang pengepul adalah Rp. 7.000,- per kilogram, dari pedagang pengepul ke pedagang besar adalah Rp. 7500,- per kilogram, dari pedagang besar ke pengecer adalah Rp.8.000,- per kilogram. Maka besarnya nilai Producer's Share tepung aren adalah :

Producer's Share saluran pemasaran $=\frac{P f}{P r} \times 100 \%$

Producer's Share saluran Pemasaran = $\frac{7000}{9000} \times 100 \%$

Produser's Share saluran pemasaran $=$ $77,77 \%$

Hasil perhitungan menunjukkan bahwa nilai Producer's share untuk saluran pemasaran tepung aren adalah $77,77 \%$ dari harga yang dibayarkan konsumen.

\section{Efisiensi Pemasaran Tepung Aren}

Sistem pemasaran dianggap efisien apabila mampu menyampaikan hasil-hasil dari produsen kepada konsumen dengan biaya wajar serta mampu mengadakan pembagian yang adil dari keseluruhan harga yang dibayarkan konsumen.

Biaya pemasaran yang dikeluarkan lembaga pemasaran saluran 1 adalah total biaya yang di keluarkan selama proses pemasaran tepung aren adalah Rp. 365 per kilogram, total keuntungan pemasarannya Rp.1.635 per kilogram. Bila dilihat dari saluran pemasarannya, saluran pemasaran tepung aren ini efisien yaitu sebesar 0.05 $\%$.

\section{KESIMPULAN DAN SARAN \\ Kesimpulan}

Berdasarkan hasil penelitian dan pembahasan, maka dapat diambil kesimpulan sebagai berikut :

1) Terdapat satu saluran di tingat 3 lembaga pemasaran tepung aren sampai ke tangan konsumen akhir yaitu sebagai :

Produsen $\rightarrow$ Pedagang Pengepul $\rightarrow$

Pedagang Besar $\rightarrow$ Pedagang Pengecer $\rightarrow$ Konsumen Akhir.

2) Pada saluran ini melibatkan beberapa lembaga pemasaran yaitu pedagang pengepul, pedagang besar dan pedagang pengecer. Besarnya margin pemasaran pada saluran ini adalah sebesar Rp. 2.000,- per kilogram sehingga keuntungan total pemasaran sebesar Rp. 1.635,-- per kilogram.

3) Besarnya bagian harga yang diterima produsen (producer's share) pada saluran pemasaran ini adalah sebesar $77,77 \%$. 
4) Total biaya yang dikeluarkan selama proses pemasaran tepung aren adalah Rp. 365,- per kilogram, total keuntungan pemasarannya $\mathrm{Rp}$. 1.635,- per kilogram. Bila dilihat dari saluran pemasarannya, saluran pemasaran tepung aren ini efisien yaitu sebesar $0.05 \%$.

\section{Saran}

Berdasarkan kesimpulan diatas maka dapat disarankan hal-hal sebagai berikut :

1) Saluran pemasaran di Desa Kertaharja ini terdapat 1 saluran pemasaran dimana produsen disini berperan langsung sebagai pengepul dan menjual produknya ke pedagang perantara yaitu ke pedagang besar. Dalam kondisi ini pedagang masih bisa memonopoli dalam penentuan harga. Untuk itu perlu dibuka akses saluran pemasaran lainnya sehingga produsen akan lebih diuntungkan.

2) Produsen harus lebih bisa aktif dan kreatif lagi dalam mencari informasi untuk memasarkan produk tersebut, sehingga produk yang dipasarkan bisa lebih luas jaringannya.

\section{DAFTAR PUSTAKA}

Daniel, 2003. Kepemimpinan Yang Mendatangkan Hasil. Cetakan Pertama, Amara Books. Yogyakarta

Desa Kertaharja 2018. Laporan Tahunan Pertanggungjawaban. Kecamatan Cijeungjing. Ciamis.

Hanafie R, 2010. Pengantar Ekonomi Pertanian. Penerbit Andi. Yogyakarta.

Kolter dan Keller, 2007. Manajeman Pemasaran. Jilid 1 edisi kedua belas, PT. Indeks, Jakarta.

Mulyadi, 1991. Akuntansi Biaya Untuk Manajemen. Yogyakarta :BPFEUGM.

Musstofa. 2008. Perkembangan Bahasa dan Anak Efisiensi Pemasaran Produk Pertanian. Diakses 15 April 2017.

Sugiyono, 2007. Metode Penelitian Kuantitatif dan $R \& D$. PT Alfabeta : Bandung

Sukandarrmidi, 2006. Metode Penelitian. Yogyakarta.: Pers UGM.

Soekartawi, 2005. Agroindustri Dalam Perspektif Sosial Ekonomi. Raja Grafindo Persaba : Jakarta

Suprapto. 2008. Karakteristik Penerapan dan Pengembangan Agroindustri Hasil Pertanian di Indonesia. Universitas Mercu Buana. Jakarta.

Sutarno, 2014. Ekonomi Dan Perusahaan. Fakultas Ekonomi Universitas Slamet Riyadi : Surakarta. 